\title{
A Study on Creation and Development of Wine Tourism Circuits in Maharashtra
}

\author{
Anupama Kotur Kaddi ${ }^{*}$
}

\section{Abstract}

Wine Tourism in Maharashtra is developing steadily owing to several initiatives on the part of wine tourism service providers. Although in a nascent stage as compared to its international counterparts, wine tourism in India is domestically growing as a form of special interest tourism. Wine tourism in Maharashtra, as a niche form of tourism, made its beginning with several wineries offering wine tours within their vineyards and wineries in Nashik and Pune. If individual vineyards and wineries offering wine tourism services is the first step towards inception of wine tourism in a wine region, the creation of wine trails and wine tourism circuits is the next most logical and quintessential step towards growth of wine tourism in that region. This paper attempts to explore two important areas of wine tourism circuit creation and development in Maharashtra which also form the objectives of this study. They are (a) what are the most important considerations during the creation of wine tourism circuits in wine regions? And (b) what are the opinions of wine tourism service providers on the creation and development of wine tourism circuits' in wine regions of Maharashtra? For the purpose of this study, both primary and secondary sources of data were used. For collection of primary data, a survey was conducted among the wineries of Maharashtra to study their opinions on creation of wine tourism circuits. Through the findings of this paper, an attempt has been made to study the various important aspects that are

* Research Scholar, IGNOU, New Delhi, India; anukotur@gmail.com 
perceived important by the wineries for creation of wine tourism circuits. The paper in conclusion suggests measures to create and develop wine tourism circuits in the wine regions of Maharashtra. Further, this paper is also aimed at forming the basis for further research on wine tourism management in Maharashtra.

Keywords: Wine tourism in Maharashtra, Wine trails, Wine tourism circuits, Wineries.

\section{Introduction}

Wine tourism is niche tourism as much as it is a form of special interest tourism. Wine industry in Maharashtra, which saw a fast paced growth in early 2000, is today the largest producer of wines in India. Wine tourism, but an obvious development in Maharashtra, today, is offering a wide range of wine tourism products and services such as vineyard resorts, wine festivals, vineyard-based events and wine tours clubbed with various vineyard based activities for wine enthusiasts. While Indian wine tourism product has made its debut in the global wine tourism market, for it to distinguish itself from others, wine tourism in Maharashtra must acquire a regional identity. A destination image based on regional identity is the most important and primary step towards brand building of wine tourism product in India. This regional identity by way of distinguishing every wine region based on its location enables in product differentiation. Bruwer (2003) argued that 'in today's world wine market what is important to acknowledge is that successful building of the brand identity and image of the winery, the wine region and the wine country of origin is, arguably, the single most important factor that will determine future success in the wine industry' and therefore the success of wine tourism in the region. Wine routes or most popularly identified as wine trails and wine tourism circuits, lend a regional image to wineries and vineyards located in those regions. With this as the background, two important objectives guide this study viz., (a) what are the most important considerations during the creation of wine tourism circuits in wine regions? And (b) what are the opinions of wine tourism service providers on the creation and development of wine tourism circuits' in wine regions of 
Maharashtra? Through this study an attempt has been made to identify all those aspects that must be considered while developing wine tourism circuits in a region. Also the study aims at understanding the opinions of wineries or wine tourism service providers on the creation of wine tourism circuits in Maharashtra. In conclusion, the research paper, suggesting various possible wine tourism circuits in Maharashtra, elaborates various suggested measures for creation and developing wine trails and wine tourism circuits in the state.

\section{Literature Review}

\section{Wine Tourism in Maharashtra}

A matured wine industry is but imperative to the growth and development of wine tourism. Any study on wine tourism in Maharashtra cannot be undertaken in isolation, without understanding wine industry in the state. The state of Maharashtra saw the establishment of India's first international standard winery in the early 1980's in Narayangaon near Pune. Five more were established and functional by the year 2000. The decade that followed can be considered significant for Indian wine industry as over 60 wineries came into being. Nashik, Pune, Sangli, Solapur and Osmanabad are important wine regions in Maharashtra. As per a report by Dr. Hande (2013), in Maharashtra, total area under grape cultivation is 7000 acres with annual production of 15 Lakh Metric Tons of grapes. 'The industry, which was barely 150,000200,000 cases (of wines) strong at the turn of the millennium, was growing at the rate of $25-30 \%$ for the five years prior to the downfall in 2008; it reached a peak of $1.5 \mathrm{~m}$ cases, including about 250,000 cases of imported wines. The years 2008 to 2011 saw a slide in the domestic wine production and consumption, though the market flirted with a peak in April to March 2011 to 2012, and a growth of $20 \%$ to $25 \%$ is expected to continue over the next five years' (sic) (Arora, 2013). 'The total investment on wineries in Maharashtra was Rs. $431.71 \mathrm{Cr}$ in 2009 and rose to Rs. $452.10 \mathrm{Cr}$ in 2012' (Hande, 2013). The current statistics for the year 2014 by All India Wine Producers' Association (AIWPA) indicate that there are as many as 75 wineries across the state. However, 'as many as 50 
wineries including 30 in Nashik are in financial trouble and have stopped production' (TOI report as on 8th December 2014). While some larger wineries in the state such as Sula, Zampa-Grover, Fratelli, Vallonne and Charosa continue to grow, the other wineries are faced with financial crisis combined with low sales of their wine brands.

Wineries in Maharashtra, having realised the benefits of wine tourism's inclusion into mainstream winery operations, are now open to venturing into wine tourism. Nashik district of Maharashtra, being the most important wine region in Maharashtra, has become the primary location for all the wine tourism initiatives in the state. While Nashik has emerged as the hub of wine tourism activities in the state with some of the most important vineyards located there such as Sula, York, ZampaGrover, Vallonne, Reveilo and Charosa, Pune too gives competition with its wineries located nearby such as Four Seasons and Fratelli. Other important districts of Sholapur and Sangli hold fair potential to be promoted as wine tourism regions.

\section{Wine Trails and Wine Tourism Circuits}

Wine and tourism industries are akin in terms of their regional identity. While tourism attractions are recognised by their area of location or country, wines are recognised by their area of origin. Wine trails or wine routes are a concept that defines the wineries and vineyards located in certain area under one route or trail. Creation of wine trails or wine routes enables promotion of wine tourism circuits thereby giving a geographical definition to the tourism infrastructure development that is undertaken to facilitate tourism in wine regions. Wine routes and wine tourism circuits are travel routes in wine regions taking the wine tourists on defined travel routes where they visit vineyards and wineries along the wine trail. Wine tourism circuits may comprise of wine based tourist attractions alone or may combine other non-wine tourist attractions as well with wine tours. 'Wine route is defined as basically a tourist route that connects several wine estates and wineries in a given area (German: 'weinstrasse'). This route is characterised by natural attractions (mountains and other scenery), physical attractions (facilities such as wineries on wine estates), 
vineyards, and roads and markers (signposts) directing the tourist to the individual wine route estate enterprises. Most if not all wine routes are characterised by a bounded space in the form of an often officially demarcated wine region or geographical indication (GI) that has an identity in the form of a (branded) descriptive name such as Champagne (France) or Stellenbosch (South Africa)' (Bruwer, 2002).

Wine trails and wine tourism circuits may be created for varying length of duration of visits. Smaller wine trails may comprise of single day visit trails where only a few vineyards make up the wine trail. Wine trails may be developed for several days of travel depending on the extent of growth of wine industry in that region. According to Bruwer (2002), 'in considering the question of proximity, the following factors may be taken into account:

- Geographical distance between the generating region and the tourist destination

- Travel time needed to cover the geographical distance

- Amount of money required by the tourist to cover the geographical distance

- Cognitive distance between the generating region and the destination.'

The above factors may be considered while developing wine trails and wine tourism circuits in different wine regions of Maharashtra. However, it is important to understand the wine tourist typology before wine trails are developed to be able to suit the needs of all types of tourists. Bruwer (2002) further states that 'a research study pinpointed this at $180-200 \mathrm{~km}$ (one-way) in South Africa'. Wineries not located within this radius should seriously consider forming liaisons with tour operators taking visitors on 2-3 day winery tours and with their local accommodation industry, or alternatively invest in their own overnight facilities.'

\section{Research Objectives}

Despite wine tourism in Maharashtra attracting growing number of wine tourists in the last decade, the wine regions do not have any defined and demarcated wine routes or wine tourism circuits. In the 'growth phase' of Indian wine tourism, a study on creation and 
development of wine tourism circuits is but essential. Through this paper, the researcher attempts to address two most important questions, viz.,

a) What are the most important considerations while creation of wine tourism circuits in wine regions?

b) What are the opinions of wine tourism service providers on the creation and development of wine tourism circuits in wine regions of Maharashtra?

The findings of this paper can be instrumental for wine tourism service providers in creation of wine tourism circuits in various wine regions of Maharashtra.

\section{Research Methodology}

The data for the purpose of the study is both primary and secondary in nature. Largely secondary sources were used for answering the first objective and primary data was used for the latter. A survey questionnaire was constructed after reviewing various research works undertaken in wine tourism circuits, wine routes, wine tourism facilities and other allied areas. Some of the notable research works referred to were by Alonso (2005), Ministry of Tourism, India (2010) and Kirkman (2010). The population for the survey comprised of all the wineries in Maharashtra. Respondents were asked to indicate the level of importance they attached to each of the 8 listed factors essential for creation and development of wine tourism circuits in Maharashtra. Likert scale was used for the respondents to rank the importance they attached to each of the factors necessary for creation and development of wine tourism circuits. Sampling method adopted was purposive sampling. Primary data collection was undertaken by the author through self-administered surveys at wineries in Nashik, Pune and Baramati. Among the 72 wineries 30 were operational and willing to participate in the survey. A total of 23 responses were deemed usable post a thorough process of scrutiny. To test for internal consistency of the instrument, Cronbach's Alpha test was used and the results indicated a good internal consistency with an alpha value of $\alpha=.827$. 


\section{Data Analysis}

The data analysis of the importance that wineries attached to factors essential for creation and development of wine tourism circuits indicated the following results. The Friedman Rank Sum Test was carried out to test for statistical significance of the results obtained. Table 1 indicates the results as below:

Table 1: Friedman's Rank Sum Test Results Opinion of Vineyards and wineries on Wine Trails and Wine Tourism Circuits

Ranks

\begin{tabular}{|l|c|}
\hline & Mean Rank \\
\hline $\begin{array}{l}\text { Established wine trail and wine tourism circuit in the } \\
\text { wine region }\end{array}$ & 1.20 \\
\hline $\begin{array}{l}\text { Potential for development of wine tourism circuit in } \\
\text { the wine region }\end{array}$ & 3.54 \\
\hline $\begin{array}{l}\text { Being a part of popular wine tourism circuit is } \\
\text { advantageous }\end{array}$ & 5.54 \\
\hline $\begin{array}{l}\text { Joint marketing with government is beneficial to } \\
\text { promoting wine tourism }\end{array}$ & 4.87 \\
\hline $\begin{array}{l}\text { Joint marketing with other wineries is beneficial for } \\
\text { promoting wine tourism }\end{array}$ & 5.17 \\
\hline $\begin{array}{l}\text { Creating and being a part of wine tourism consortium } \\
\text { is beneficial }\end{array}$ & 5.50 \\
\hline $\begin{array}{l}\text { Good inter-connecting roads essential for wine } \\
\text { tourism circuit }\end{array}$ & $\begin{array}{l}\text { Cooperation essential among wineries for creation of } \\
\text { wine tourism circuits }\end{array}$ \\
\hline
\end{tabular}

Test Statistics a

\begin{tabular}{|l|l|}
\hline N & 23 \\
\hline Chi-square & 90.438 \\
\hline Df & 7 \\
\hline Asymp.Sig & .000 \\
\hline
\end{tabular}

The Friedman Mean Ranks above indicate that factors, 'Joint Marketing with Government for wine tourism' (5.54), 'Cooperation among Vineyards and Wineries' (5.50) and 'Good Interconnecting roads between the vineyards' (5.37) emerged with high Friedman Mean Ranks indicating a very favourable opinion towards these aspects for creation and development of wine trails and wine 
tourism circuits in the wine regions of Maharashtra. While other factors, 'Creation of Wine Tourism Consortium' (5.17), 'Joint Marketing with Other Vineyards' (4.87), 'being a part of a popular wine tourism circuit advantageous for smaller wineries' (4.80) too indicate a favourable and positive opinion about wine trails and circuits. However, most of the respondents were unanimous in the opinion that there did not exist any established wine trail or circuit in the regions with a Friedman Mean value of 1.20. Through this investigation, it can be inferred that vineyards and wineries showed positive indication towards creating and being a part of wine trails and tourism circuits.

\section{Suggestions and Conclusion}

Wine routes or wine tourism circuits, are essentially combinations of wine as well as non-wine attractions including the natural setting of the wineries. The literature review highlights the various factors that must be considered while creating wine routes. Further, the data analysis indicates all those areas that are elemental in developing wine tourism circuits as perceived by the wineries. Almost all participating wineries were of the opinion that although there existed tremendous potential for creation of wine tourism circuits, no defined wine tourism circuits are present in Maharashtra. The data analysis also indicated that wineries were highly in favour of joint marketing with tourism development authorities in the state to initiate actions towards the creation of wine tourism circuits. Wineries also opined that there is a need for greater cooperation among wineries in the state to develop wine routes. Good interconnecting roads also were seen as extremely important for creating wine routes.

Although, wine regions of Maharashtra are well endowed with other tourism resources, there is a need to develop wine tourism circuits comprising of wine attractions as well as others. Suggested below (Table 2) are 6 important wine trails and wine tourism circuits can be developed in the wine regions of Maharashtra. Presently, Sawargaon Region Trail is the popular and the only operational wine tourism circuit in Nashik. 
Table 2: Suggested Wine Routes and Wine Tourism Circuits for Maharashtra

\begin{tabular}{|c|c|c|}
\hline $\begin{array}{l}\text { Wine } \\
\text { Tourism } \\
\text { Regions }\end{array}$ & $\begin{array}{l}\text { Suggested Wine } \\
\text { Routes / Trails }\end{array}$ & $\begin{array}{c}\text { Suggested Wine Tourism } \\
\text { Circuits }\end{array}$ \\
\hline \multirow{4}{*}{ Nashik } & $\begin{array}{c}\text { Sawargaon Region } \\
\text { Trail }\end{array}$ & $\begin{array}{l}\text { Sula -York - Soma Vineyards - } \\
\text { Sawargaon Reservoir }\end{array}$ \\
\hline & Dindori Region Trail & $\begin{array}{l}\text { Seagram's Nine Hills- Chateau } \\
\text { D'Ori- Charosa Vineyards }\end{array}$ \\
\hline & $\begin{array}{c}\text { Igatpuri / Sanjegaon } \\
\text { Region Trail }\end{array}$ & $\begin{array}{l}\text { ZampaGrover - Vallonne } \\
\text { Vineyards - Igatpuri Reservoir - } \\
\text { Pandavleni Caves }\end{array}$ \\
\hline & Vinchur Region Trail & $\begin{array}{l}\text { Vinsura (Godavari Wine Park)- } \\
\text { Reveilo Vineyard }\end{array}$ \\
\hline \multirow{2}{*}{ Pune } & Haveli & $\begin{array}{l}\text { Deccan Plateau Vineyards - } \\
\text { MorachiChincholi }\end{array}$ \\
\hline & Baramati Region Trail & $\begin{array}{l}\text { Four Seasons Vineyards- Fratelli } \\
\text { Vineyards - Jejuri Temple }\end{array}$ \\
\hline
\end{tabular}

Wine trails and wine tourism circuits can be instrumental in bringing about an organised and integrated wine tourism product into Maharashtra's tourism repertoire. Besides creating wine routes other aspects pertaining to the development of wine tourism circuits must be given considerable importance. Below discussed are suggested measures that need due consideration in order to create and develop wine tourism circuits in Maharashtra:

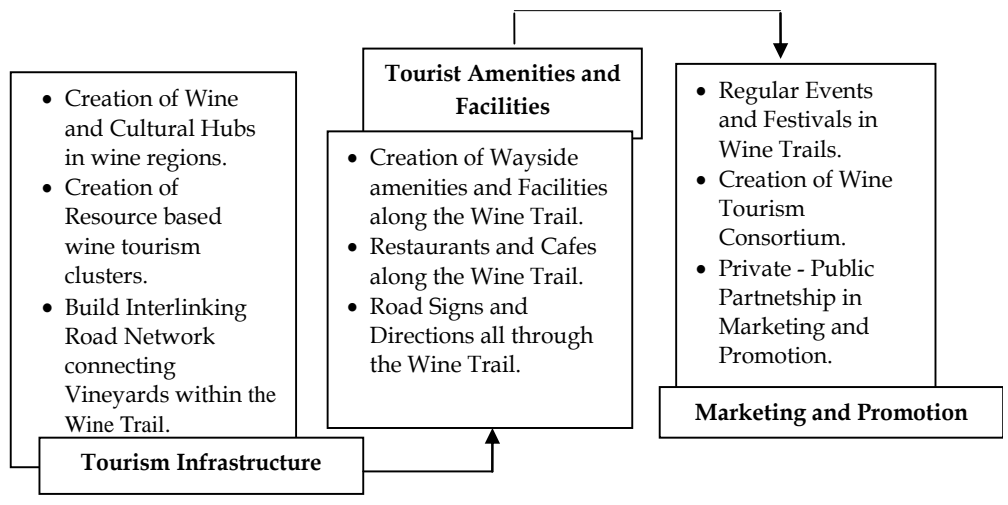

Fig 1: Suggested Measures for Creation and Development of Wine Trails and Wine Tourism Circuits in Maharashtra 
a) Creation of Wine and Cultural Hubs in Wine Regions is an essential step before developing wine tourism circuits. Wine is the primary attraction in wine tourism. However, inclusion of other secondary attractions in wine regions will not only diversify tourism offerings in wine regions but also create a unique tourism product that blends wines with indigenous culture. Local cultures such as food, dance, folklore, agriculture, rural lifestyle, adventure tourism and natural scenery may be blended into the wine tourism experience in order to create a unique Wine - Cultural hubs in every wine region. Through this other forms of tourism too can be encouraged to a considerable extent.

b) Creation of Resource Based Wine Tourism Clusters must be considered while developing wine tourism circuits. Every wine region in Maharashtra is endowed with features that set it apart from other wine regions. While Nashik is endowed with natural beauty and historic attractions, Baramati and Sangli regions are suitable for the development of agro-rural tourism. Efforts must be made to recognise secondary tourism resources in the wine regions and provide assistance by MTDC to convert those resources into tourism attractions. The assistance provided may be in the form of manpower training, financial assistance or tourism infrastructure development to enable conversion of the tourism resources into tourist attractions. Wine Tourism cluster, comprising of wine tourism attractions of Vineyards and wine parks amalgamated with other secondary tourism attractions may be classified as 'Wine Tourism Clusters'.

c) Building interlinking network of roads is most essential to create accessibility to and within the wine trails and wine tourism circuits. The accessibility must be created keeping in mind the travel time and most convenient route to travel within the circuit.

d) Along the road network in wine trails, proper signs and directions must be installed to be able to assist the wine tourists and ease their travel. MTDC may consider opening 'May I Help You' centres at the beginning of the wine trails, and further develop these centres as 'Wine Tourism Visitor Centres'. 
e) Creation of wayside amenities along the wine trail such as restrooms, ATMs, facilities for refreshment such as cafes and restaurants further facilitate wine tourists.

f) Regular wine events and festivals may be conducted all through the year, especially during lean seasons to ensure wine tourist movement all-round the year. This will help generate revenue for the locals who are dependent on wine tourism generated revenue.

g) Creation of wine tourism consortium among the wineries for joint promotion of wine routes within the various wine regions of Maharashtra.

h) Private -Public partnership will ensure funding for creation and development of wine routes and wine tourism circuits in Maharashtra.

\section{References}

Alonso, A. D. (2005). Wine Tourism Experience in New Zealand: An Exploratory Study. (Doctoral thesis for the Lincoln University, New Zealand). Retrieved from researcharchive.lincoln.ac.nz/bitstream/10182/1046/1/alonso _phd.pdf

Arora, S. (2013). India's emerging wine industry. Wine Business International. Retrieved from http://www.wine-businessinternational.com/156-

bWVtb2lyX2lkPTQ4NiZtZW51ZV9jYXRfaWQ9Mw--enmagazine- magazine_detail.html

Bruwer, J. (2002). South African wine routes: Some perspectives on the wine tourism industry's structural dimensions and wine tourism product. Elsevier Science Ltd. Retrieved from http:/ / turismorural.org.br/download/20080611132932.pdf

Hande. (2013). Agricultural Officer, Grapes Division; Ministry of Agriculture, Pune, Maharashtra; Private Communication

Kirkman, A. (2010). The role of wine tourism in the marketing of wineries in the Stellenbosch wine route of South Africa. Masters' thesis submitted to University of South Africa. Retrieved 
from http://uir.unisa.ac.za/bitstream/handle/ 10500/ 4928/ thesis_kirkman_a.pdf?sequence $=1$

Ministry of Tourism (Market Research Division), Government of India. (2010). Summary report on Infrastructure gaps in tourism sector at five tourist destinations in India based on perception of tourists. Retrieved from http:/tourism.gov.in/CMSPagePicture/file/marketresearch/st udyreports on evaluation of plan schemes/ 01\%20Report\%20Vol-II.pdf

Times of India. (2014). 'Sick wineries in state await govt. funds for revival'. 8th December. 2014. P 5. 